\title{
THE SUPERPOWERS AND INTERNATIONAL INSTITUTIONS
}

\author{
MARC BENNETT
}

University of Michigan

his research note evaluates methods for explaining the fact
that to a striking degree in the 1980s, superpower policies and
attitudes concerning the United Nations evolved in opposite directions. While the U.S. has over the last decade reduced - and in some cases (e.g., the United Nations Conference on the Law of the Sea and UNESCO) renounced-its interest in international institutions, the U.S.S.R. has recently shown a new enthusiasm for the UN itself, its peacekeeping operations, ${ }^{1}$ and its agencies. The Soviets asked the General Assembly for three consecutive years to consider its proposal for creating a "comprehensive system of international peace and security." Overall, shifts in Soviet UN policies are ". . . evident in such diverse places as Afghanistan; Angola; Lebanon; the Persian Gulf; the General Agreement on Tariffs and Trade (GATT); the International Atomic Energy Agency; [and] UNESCO ..." (Luck and Gati 1988: 19). ${ }^{2}$

In order to develop ways of solving the puzzle of differing trends in superpower actions and outlooks, this paper explores various indicators of U.S. and Soviet attitudes toward international institutions. It should be noted at the outset that the data sets which I use to examine the outlooks within each country are not directly comparable. Despite

Received: April 11, 1990

First Revision Received: July 9, 1990

Second Revision Received: August 8, 1990

Accepted for Publication: August 13, 1990

NotE: This is a revised version of a paper first presented at the 1989 Annual Meeting of the Midwest Political Science Association, Chicago, IL. I would like to thank Matthew Evangelista, William Zimmerman, several anonymous reviewers, and the editor of this journal for their comments and suggestions. Of course, I alone am responsible for any errors.

${ }^{1}$ For example, an article in the Soviet army newspaper noted that, "Showing the UN flag is something which helps keeps in check the possibility of armed conflict." (Markushin, 1988: 5) I am indebted to Matthew Evangelista for bringing this article to my attention.

${ }^{2}$ See Kozyrev (1990) for a recent, comprehensive Soviet perspective on the United Nations. 
the startling changes in the U.S.S.R. during the Gorbachev era, it is still difficult to study Soviet policy-making and policy-makers' attitudes directly. I employ content analysis of Soviet political journals as a surrogate for the public-opinion and case-study data which are available on the U.S. side. In short, I am presenting my data as preliminary evidence of what I believe to be important differences between U.S. and Soviet approaches to international organizations (IOs).

As the framework for my discussion, I consider two possible models of state involvement with international institutions. One explanatory model is based on a realist analysis of international relations; it emphasizes external pressures on states in the anarchic world system and assumes that states behave as rational, unitary actors. The competing model, by contrast, concentrates on the internal, domestic political ramifications of given types of issues, or "issue-areas." The issuearea model rejects realism's assumptions about states as rational, unitary actors.

\section{The Realist Model}

A useful model for conceptualizing states' involvement in international organizations should convey the costs and benefits of such involvement. A model of nations' policies toward international institutions ${ }^{3}$ must also take into consideration the fact that IOs are created and maintained by means of states' collective action. Olson's Logic of Collective Action (1965) provides some important theoretical assumptions which undergird a realist model of the superpowers' IO policies. Such a model sees states' behavior in the international system fundamentally as a function of systemic constraints and opportunities. The international allocation of state capabilities is the main influence on international relations.

As the U.S. loses its hegemonic status, the configuration of the group of states involved in the collective act of providing and maintaining the UN changes. No longer a "privileged" group in which one member dominates, the group is more of an intermediate-sized one, in which no single member benefits so greatly from the collective good that he is willing to provide the good himself. Olson makes it clear

\footnotetext{
${ }^{3}$ International institutions are defined as "recognized patterns of practice around which expectations converge." (Young, 1982: 280) International organizations, such as the United Nations and its agencies, are the specific arenas for these "patterns of practice."
} 
that once a group is in the "intermediate" category, the incentive for individual members to contribute toward the provision of the collective good falls dramatically. The realist model, incorporating Olson's framework, predicts that as the relative size (i.e., power) of states decreases, so will their willingness to contribute to IOs.

When tested against the empirical evidence, the predictions derived from Olson's argument about different sorts of small groups capture broad trends well. As the leader of a "privileged" group for the period 1945-60, the United States cast no vetoes in the Security Council of the United Nations. It is generally acknowledged that in the early postwar years, when the U.S. share of world industrial production neared fifty percent “. . . the U.S. could command the UN's agenda ..." (Franck 1985: 246).

In the contemporary world, the sharp increase in the number of UN members also accounts for the fact that a situation closer to the one depicted in Olson's "intermediate"-group scenario exists. By the mid-1960s, " . . . with UN membership exceeding 120, the United States had fallen to a minority position on more than half of UN contested votes" (Riggs and Plano 1988: 348). At the same time, American global economic power has declined. Over the years 1950-81, American petroleum output fell from 51 percent of world output to 16 percent; crude steel production from 45 to 20 percent; and iron ore, from 42 to 11 percent (Krasner 1985: 71). The European Economic Community's collective gross national product now exceeds that of the U.S. (Schmeisser 1988). As an indication of a corresponding slackening of support for IOs, American contributions to the UN budget have decreased from 39 percent during 1946-54 and 33 percent during 1956-72 to 25 percent in the 1980s (Krasner 1985: 299). The Kassebaum Amendment, passed by the Congress in 1985, stipulated that the American share would unilaterally be reduced to 20 percent until the UN reformed its budget-making procedures.

The United Nations' scheme for assessing the budget shares which members are expected to contribute is implicitly based on a linkage of states' power (measured by GNP) with their consumption of the collective goods provided by the UN. In other words, "the main criterion for capacity to pay has always been gross national income" (Franck 1985: 256). The assessments are based on GNP figures provided by the individual country, so the opportunity exists for nations to present data that help reduce their fiscal burden. The U.S.S.R.'s assessment shrank from 11.6 to 11.1 percent from $1979-82$, and continued to 
decline, to 10.54 for $1983-85$. Over the same period, by way of contrast, the Japanese assessment has increased from 8.5 percent to nearly 10.5 percent. The US registered complaints about the accuracy of national income figures given by the Soviets, and the US voted against the decreased Soviet 1983-85 contribution (Yearbook of the United Nations 1982: 1217-20). By 1988, the Soviet assessment had increased to 11.8 percent (New York Times, 1988: August 7).

Apart from assessments, there is the question of the extent to which UN members live up to their financial obligations. In this regard it is worth noting that as the 1980s ended, the UN's financial condition had improved. In 1988 the Soviet Union, which had owed over $\$ 50$ million to the UN as of 1984 , fully paid its debt (The Economist 1988: March 12, p. 44). In 1989 the United States still owed $\$ 350$ million in unpaid assessments, but in that year the U.S. pledged to pay all of its regular budget assessment and to begin making good on its pre-1989 arrears (Lister 1990: 223).

While modeling state involvement in IOs as a function of rational cost/benefit decisions is of some use in understanding contemporary superpower policies toward international institutions, it is only partially successful in addressing the query which this paper seeks to answer. The realist model does successfully predict that states in a situation akin to the one in which Olson's "intermediate" group finds itself will be less eager to contribute to the provision of a collective good. The empirical evidence shows a broad correlation between the relative power of states and their actual, not merely nominal (assessed), contributions to IOs. Olson and Zeckhauser's analysis shows a statistically significant correlation between individual states' GNP figures and their UN contribution in terms of percentage of assessment actually paid (1968: 40). However, the main disadvantage of the realist model is that its predictions are overly broad. Specifically, it does not explain why Soviet and US attitudes toward the UN evolved in opposite directions in the 1980 s.

\section{Soviet New Thinking and InTERnATIONAL Institutions}

In this section I discuss contemporary attitudes among Soviet foreign policy elites concerning global interdependence and related questions. Recent data indicate a clear surge in the importance accorded to these issues on the part of the Soviet foreign policy establishment. This result is relevant to the present inquiry in that the new Soviet 
policy toward international institutions is conceptually rooted in a view of the world which emphasizes global interdependence. "Gorbachev's more active global diplomacy - stressing global interdependence, the need for mutual security, and increased contacts among states-provides the ideological underpinning for a more engaged UN policy" (Luck and Gati 1988: 23).

Table 1 reports the results of a content analysis of three prominent Soviet journals. For the period 1983-89, I measured the yearly number of articles in each publication which favorably mentioned the concepts of greater global economic interdependence and/or mutual (global) security. The appearances of such articles in the journals Mirovaia Ekonomika i Mezhdunarodnie Otnosheniia (MEMO), Mezhdunarodnaia Zhizn' (MZh) and Kommunist ${ }^{4}$ were used to indicate where interdependence-oriented issues have been located on the Soviet policy agenda in recent years. These are the official publications of, respectively, the Institute of the World Economy and International Relations, the Soviet Foreign Ministry, and the Communist Party of the Soviet Union.

TABLE 1

Yearly Number of Pro-Interdependence Articles, 1983-1989

\begin{tabular}{cccc}
\hline \hline Year & Kommunist & MEMO & MZh \\
\hline 1983 & 1 & 4 & 0 \\
1984 & 0 & 4 & 2 \\
1985 & 1 & 9 & 3 \\
1986 & 5 & 10 & 6 \\
1987 & 6 & 8 & 8 \\
1988 & 6 & 8 & 7 \\
1989 & 7 & 14 & 11 \\
\hline
\end{tabular}

In terms of the number of "pro-interdependence" articles published, the trend is clearly in the upward direction for each journal. Measured differently, the increase is seen in the fact that the percent-

\footnotetext{
${ }^{4} \mathrm{~A}$ quantitative analysis of the general positions taken by the leading organs of the Soviet press on a major foreign policy question - what lessons should the USSR derive from the American experience in Vietnam-established the existence of appreciable overall variation in outlook. (Zimmerman and Axelrod, 1981). With the advent of glasnost' in the Gorbachev era, Soviet journals and newspapers have become fairly open about disagreeing with stances taken by one another.
} 
age of $M E M O$ articles on interdependence doubled between 1983 and 1986 (from 1.57 to 3.20 percent), and then dropped slightly between 1986-88 (to 2.53 percent and then 2.58 percent). In 1989 MEMO started a new section of the journal devoted to articles on "problems of the integrated world," and the percentage increased again, to 4.59 percent. For $M Z h$, the analogous figure went from 3.9 percent in 1984 to a high of 11 percent in 1987 , before decreasing to 7.86 percent in 1989. Finally, the percentage of articles favorably mentioning interdependence in Kommunist more than doubled over the 1983-89 period.

Measuring the number of articles concerned specifically with international organizations reveals a different trend. The number of articles in the section of $M Z h$ concerning "international forums and organizations/international law" amounted to 27 in 1981, dipped to 12 by 1984, and increased to 33 and 28 in 1986 and 1987, respectively. (The journal eliminated this category at the end of 1987, at which time it began including articles on IOs in the main section on international relations). While there are several plausible interpretations of this finding, it appears to indicate that there was little linkage of the new academic interest in interdependence to Soviet thinking on IOs prior to Gorbachev's accession to power in 1985.

The Gorbachev-era "new thinking" on international institutions is new not in that it envisions a prominent role for international organizations, but in that it depicts them as arenas more for cooperation with the West than for competition. As evidence of this innovation, consider a representative quotation from a typical Brezhnev-era article on the UN: "... [V]irtually all major initiatives and proposals have been advanced by the Soviet Union ... The 35-year record of the UN is the history of struggle between the two opposing courses in the international sphere" (Petrovsky 1980: 11-12). By contrast, Gorbachev noted in his December 1988 speech that "for many years [the UN] was a propaganda battlefield . . . [T]his chapter in the history of the United Nations . . . was at variance with the very essence and mission of the UN" (Gorbachev 1988: 2).

\section{The Issue-Area Model}

I now describe an alternative to the realist model, the need for which the previous section's empirical findings make clear. The evidence points to an unprecedented Soviet interest both in global interdependence as a concept and in international organizations as arenas 
for managing interdependence. To understand why this interest has arisen, and how it affects Soviet policy concerning international institutions, I employ an issue-area model in order to supplement realism.

Zimmerman (1973) argues that the policy processes which tend to accompany, for example, the issue-areas of crisis politics and diplomatic recognition are similar because the impact of the outcomes will be the same for nearly all citizens. The symmetry of the impact obtains regardless of whether that impact is monumental (as in a crisis) or trivial (as in diplomatic recognition). A limited war-such as the American involvement in Vietnam-is an example of an issue with an asymmetrical impact, since the burden of fighting the war tends to fall more heavily on some segments of the population than on others.

Apart from symmetry, the other important issue-area characteristic concerns whether exclusively tangible resources are at stake. If there is nothing symbolic or ideological about a given issue-area, then the relevant political process will be that of either distribution or regulation. However, if more than tangible political goods are involved, then the policy process will be similar to those found in cases of diplomatic interaction, protection of national values (as in a crisis), or redistribution of status and power.

The combination of an issue-area's symmetry and tangibility determine the extent to which decisional participants' values are at stake. Figure 1 shows a clockwise movement from minimum to maximum centrality of the stakes, as a function of changes in the tangibility and symmetry of given issue-areas. Establishing the degree of an issuearea's symmetry and tangibility also should allow for prediction of the nature of the attendant policy process, the possibilities for which are arranged in a clockwise continuum: from interaction to distribution, regulation, redistribution, and finally to protection.

The task for an issue-area model of the politics of superpower policy-making on issues concerning international institutions is first to address the questions concerning the attributes of an issue-area, i.e., tangibility of stakes and symmetry of impact. Then the model will be able to predict the expected policy process and provide a sense of how that process can best be studied. The supposed virtue of employing the issue-area paradigm is that of developing a richer, more subtle analysis than is possible "... [with] a conception of foreign policy conducted by a rational, unitary decision-maker" (Zimmerman, 1973: 1209). 
FIGURE 1

AN Issue-based Foreign-policy Paradigm

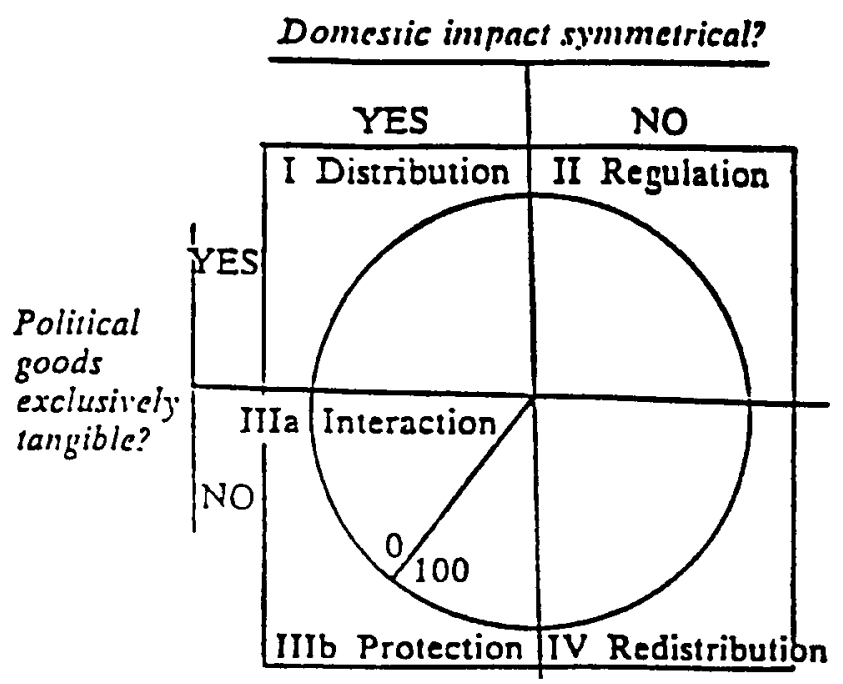

Source: Zimmerman, 1973: 1208

\section{Issue-Area Analysis of the Soviet Case}

In the late 1980s and early $1990 \mathrm{~s}$, the official Soviet view on interdependence in general and the UN in specific has been enthusiastic. Mikhail Gorbachev (1987) wrote that "the sphere of rational, responsible organization of international affairs is broadening before our eyes. . . ." Speaking at the UN in December 1988, the Soviet leader urged states to ". . . carry out a certain revision of their attitude towards such a unique instrument as the United Nations, without which world politics is inconceivable." The Soviet leader said, more generally, "If we are parts, even if different, of one and the same civilization, if we are aware of the interdependence of the modern world, this understanding should increasingly manifest itself both in politics, and in practical efforts to harmonize international relations." And, regarding the world economy, Gorbachev noted that it " . . . is becoming a single organism, outside which no state can develop normally . . ." (Gorbachev 1988: 2).

Despite Gorbachev's enthusiasm, a variety of opinions exists in the Soviet Union concerning interdependence, traditionally a very sensitive issue with both political and economic dimensions. Pravda has fea- 
tured political commentators debating the future of the UN in a lively fashion (Shakhnazarov 1988 and Bovin 1988). Given that there is in fact a range of views concerning the conceptual issue of interdependence and the practical matter of Soviet policy toward international institutions, I examine contemporary Soviet debates as a useful way to measure the domestic impact of the issue-area of international institutions. The journals used for the literature review are again $M E M O$, Mezhdunarodnaia Zhizn', and Kommunist.

The debates reveal a range of views on the ideological desirability of the various forms of cooperation with the non-socialist world. Soviet attempts at integration with the international capitalist economy are by some considered "ideological retreats" (Shenfield 1987: 73), since implicit in such efforts is the acknowledgement that the socialist bloc's system of international economic relations has not been fully successful. As an alternative to such "retreats," some Soviet discussions of global problems analyze increased interdependence in terms of a heightened role for socialism. Georgi Shakhnazarov, the first deputy head of the Central Committee Department for Liaison with Communist and Workers' Parties of Socialist Countries, has said that "[e]cological problems require socialist methods. . . . [As well,] take the World Health Organization. What is that? That is not a capitalist method, it is - at least in principle - a socialist method" (Gleisner 1987: 3).

Soviet thinkers on interdependence have waged debates over two categories of issues. Within the "globalistics" school, conservatives have been attacked for not comprehending the magnitude of issues such as AIDS, terrorism, drug addiction and the like. Others have argued that global problems represent an area of rivalry as well as cooperation between capitalism and socialism (Shenfield 1987: 62).

Concerning the general question of closer economic ties with the West, three different strands of thought exist. In 1987 a two-part review article, in itself a sign of the liveliness of the interdependence debate, outlined three schools of thought regarding the world economy. The broad interpretation depicts a truly global economy which envelops all national economies and links them together by means of the international division of labor. The narrow approach sees the world economy as a system based on economic relations between countries, or even between the separate socialist and capitalist world economies. The third, or "intermediate" approach, seeks a middle way between the two extremes (Shishkov 1987: 75). 
Gorbachev, supporting the broad interpretation, has introduced policies aimed at promoting economic interdependence which are also intended to introduce a competitive atmosphere in which some Soviet enterprises will flourish while others founder. Another aspect of the domestic impact of the new Soviet approach to the world economy can be seen in the ambivalent attitude of Soviet officials in the foreign trade bureaucracy. Their power has steadily eroded as trade becomes more decentralized in Gorbachev's effort to enlarge the Soviet role in the world economy. (In 1988, the Ministry of Foreign Trade and the State Committee for Foreign Economic Relations were abolished and replaced by a new Ministry for Foreign Economic Relations.) One bureaucrat has said, "I am working myself out of a job. [But] I don't know what I'm working myself into" (Hough 1988: 76).

Gorbachev needs his pro-reform constituency both as a base of political power and as a resource to make the economic restructuring work. Given this context, theoretical debates over interdependence have acquired political importance. Snyder notes that the president of the Soviet Academy of Sciences, Anatolii Aleksandrov, was fired after warning that an "import plague" was retarding the growth of Soviet technology and thus endangering national security (1987: 111; also see Clemens 1990: 178). This episode implies that the domestic impact of interdependence issues in the U.S.S.R. is not symmetrical.

I conclude that given an issue-area characterized by nonexclusively tangible goods and asymmetrical domestic impact, the Zimmerman paradigm would place it in quadrant IV of Figure 1 and expect a redistributive policy process to accompany the issue-area of international institutions. The issue-area of global interdependence and international institutions evidently has a redistributive effect on the Soviet polity, draining political power from the conservatives and delivering it to the Gorbachev constituency. The internal model predicts that issue-areas with asymmetrical impacts will have attendant policy processes that can be analyzed with a group-politics approach. Such a model would assert that current Soviet IO policy is a by-product of the struggle between reformers, who see the pursuit of interdependence as a viable strategy for the Soviet Union, and conservatives, who are less eager to abandon a more autarkic approach.

\section{IsSue-Area ANalysis of THE U.S. Case}

The task for the issue-area approach with regard to the U.S. case is to help explain the nature of the policy-making process which has 
been characterized by a reduced interest in international organizations. Krasner notes that while American willingness to support the UN and its agencies has not collapsed, "it has declined" (1985: 299). In 1977 the U.S. temporarily withdrew from the International Labor Organization. In 1982 the U.S. rejected the Law of the Sea Convention and refused to pay a $\$ 1$ million UN assessment for a Law of the Sea commission. The United States quit UNESCO in 1985 and also refused to participate in a World Court case, involving an ultimately successful suit brought by Nicaragua, for the first time (Krasner 1985: 300).

Survey data on public attitudes in the U.S. toward the United Nations indicate a general attitude of approval mixed with some disappointment. In 1985 more citizens thought the organization was doing a very good or good job than a poor or very poor job (51 percent vs. 40 percent). On the fundamental question of whether the world would be better off without the UN, an overwhelming majority of 78 percent replied in the negative, with only 13 percent agreeing that the world would be better off. "Even among those who said the United Nations was performing poorly, few wanted to get rid of it" (New York Times, June 26, 1985).

When the focus shifts from the U.S. public to the government, the analysis becomes more complicated. One observer has stated that "an anti-UN mood now runs through virtually the entire policy-making community, Democratic and Republican, and to a large extent the journalistic and scholarly communities as well" (Johansen 1986: 614). However, a brief review of the policy process concerning the U.S. withdrawal from UNESCO indicates that the existence of anti-UN sentiment is not equivalent to an anti-UN consensus. A careful study of U.S. elite and public opinion on the UN concludes, " . . . simultaneous support for and criticism of the UN is common to a variety of 'elites' . . ." (Martin 1983: 300). Unsurprisingly, there was a contentious debate over the UNESCO withdrawal, including a struggle within the U.S. Congress and a three-way battle among the Congress, the State Department, and the Reagan White House.

To give a summary account of the events comprising the UNESCO controversy, an appropriate place to begin is the vote in the House Foreign Affairs Committee in March 1984 over a proposal to block the Reagan Administration's announced intention to leave UNESCO. The House instead urged the establishment of a commission to study U.S. differences with the organization. In July, assistant secretary of state Gregory Newell noted that there was a possibility that the U.S. could 
change its mind about withdrawing. Then, in August, the debate grew more heated when members of the U.S. National Commission on UNESCO accused the Reagan Administration of spreading distorted information to support the decision to withdraw from the UN agency. In September, the General Accounting Office issued a report highly critical of UNESCO. U.S. withdrawal was finalized in December 1984. (New York Times 1984: March 2, July 1, August 9, September 21, December 20).

In applying the issue-area paradigm to U.S. policy-making on international institutions, it is important to recognize the low salience of UN issues in terms of public opinion. The 1985 New York Times survey of American citizens found “ . . . considerable ignorance about the United Nations, its mandate, and its activities." This ignorance may be a function of the fact that for issues such as the withdrawal from UNESCO, there is little at stake for most citizens. Furthermore, any stakes which may exist would tend to affect most citizens in the same way. In other words, it is reasonable to state that the domestic impact of the international-institutions issue-area in the U.S. is symmetrical.

As to the tangibility of the political goods involved in the international-institutions issue-area, resource allocation has been an important component of the policy debate. The Kassebaum Amendment, designed to stimulate UN budget reforms, manifests a concern with tangible political goods; the same may be said for U.S. objections to wasteful UNESCO expenditures. Nonetheless, much of the debate in the U.S. on UN policy has focused on symbolic issues revolving around conflicts between unilateral and multilateral approaches to world issues, such as the collective management of seabed mining mandated by the Law of the Sea treaty.

The combination of symmetrical domestic impact and nonexclusively tangible political goods suggests that in the U.S. case, the international-institutions issue-area should be located in quadrant III of Figure 1, which is the protection/interaction arena. In this arena, "... participants in the process [i.e., the Congress, the Executive branch, and the attentive public] act as individuals rather than as spokesmen for groups, institutions, or major strata of society" (Zimmerman 1973: 1205). The crucial difference from the Soviet case is the symmetry of impact, the presence of which in the U.S. case tends to mute the role of domestic politics. I believe that the finding of asymmetry in the Soviet case is due to the linkage of the pro-UN, pro- 
interdependence outlook with Gorbachev's overall reform package. This linkage politicizes the Soviet domestic policy process regarding the $\mathrm{UN}$, so that even if Soviet data directly analogous to those available for the American case were available, they would likely not affect my basic conclusion.

\section{Conclusion}

In this research note I have examined different indicators of Soviet and U.S. approaches to international institutions. Due to acknowledged (and to my mind, unavoidable) limitations in comparability between the data sets for the two countries, I am wary of making any wideranging theoretical claims based on this study. However, I believe that I have shown that the issue-area approach is a useful one for studying Soviet and U.S. attitudes and policy-making concerning international organizations.

Despite data limitations, my preliminary application of the issuearea model to Soviet and U.S. policies and attitudes regarding international organizations suggests that there are unique aspects to the Soviet debate on IOs. The main finding in the case of the U.S.S.R. is the strong connection between specific UN-related issues and the larger conceptual question of the proper Soviet stance toward global interdependence. Furthermore, many of the issues subsumed under the rubric of "interdependence" touch on value-laden topics such as autarky and the class-based view of international relations. On the U.S. side, the indicators which I examined provide little evidence of a similar linkage between central values and debates about IOs.

\section{REFERENCES}

Bovin, Alexander. 1988. "Mirovoe soobshestvo i mirovoe pravitelstvo." Pravda, February 1, p. 2.

Clemens, Walter C. 1990. Can Russia Change? The USSR Confronts Global Interdependence. Boston: Unwin Hyman.

Franck, Thomas M. 1985. Nation Against Nation. New York: Oxford University Press.

Gleisner, Jeff. 1987. "Banking on the Future-an Interview with Georgi Shakhnazarov." Detente 8: 2-4.

Gorbachev, Mikhail. 1988. "Speech By Mikhail Gorbachev at the UN General Assembly," Moscow News supplement to issue No. 51 (3351), pp. 1-4.

Hough, Jerry. 1988. Opening Up the Soviet Economy. Washington, DC: The Brookings Institution. 
Johansen, Robert C. 1986. "The Reagan Administration and the UN: the Costs of Unilateralism." World Policy Journal 3 (1): 601-41.

Kozyrev, Andrei V. 1990. "The New Soviet Attitude Toward the United Nations." Washington Quarterly 13 (3): 41-53.

Krasner, Stephen D. 1982. "Structural Causes and Regime Consequences." International Organization 36 (2): 185-206.

- 1985. Structural Conftict. Berkeley: University of California Press.

Lister, Frederick K. 1990. "Administration and Budget." In John Tessitore and Susan Woolfson, eds., Issues Before the 44th General Assembly of the United Nations. Lexington, MA: Lexington Books.

Luck, Edward C., and Toby Trister Gati. 1988. "Gorbachev, the United Nations, and U.S. Policy." Washington Quarterly 11 (4): 19-35.

Markushin, V. 1988. "Ikh zhdet blizhnii vostok." Krasnaia Zvezda, November 5, p. 5.

Martin, Paul D. 1983. "US Public Opinion and the UN." In Toby Trister Gati, ed. The US, the UN, and the Management of Global Change, New York: New York University Press.

Olson, Mancur. 1965. The Logic of Collective Action. Cambridge: Harvard University Press.

Olson, Mancur, and Richard Zeckhauser. 1968. "An Economic Theory of Alliances." In Bruce M. Russett, ed., Economic Theories of International Politics. Chicago: Markham.

Petrovsky, Vladimir. 1980. "The UN and World Politics." International Affairs 7: 8-20.

Riggs, Robert E., and Jack C. Plano. 1988. The United Nations: International Organization and World Politics. Chicago: Dorsey Press.

Russett, Bruce M., and Harvey Starr. 1985. World Politics: the Menu for Choice, 2nd ed. New York: Freeman.

Schmeisser, Peter. 1988. "Is America in Decline?" New York Times Magazine, April 17, pp. 24-26, 66-68, 96.

Shakhnazarov, Georgi. 1988. "Mirovoe soobshestvo upravliaemo." Pravda, January 15, p. 2.

Shenfield, Stephen. 1987. The Nuclear Predicament: Explorations in Soviet Ideology. London: Royal Institute of International Affairs.

Shishkov, Yuri. 1987. "Vsemirnoe khoziaistvo." MEMO 9: 75-83; continued in no. 11.

Snyder, Jack. 1987. “The Gorbachev Revolution.” International Security 12 (3): 93-131.

Yearbook of the United Nations 1982. United Nations, New York: Department of Public Information.

Young, Oran. 1982. "Regime Dynamics: the Rise and Fall of International Regimes." International Organization 36 (2): 277-98.

Zimmerman, William. 1973. "Issue-Area and Foreign Policy Process: a Research Note in Search of a General Theory." American Political Science Review 67 (4): 1204-12.

Zimmerman, William, and Robert Axelrod. 1981. "The 'Lessons' of Vietnam and Soviet Foreign Policy." World Politics 34 (1): 1-24. 